\title{
OS NEGÓCIOS GLOBAIS DE \\ UMA COMPANHIA COLONIAL: \\ A COMPANHIA GERAL DE PERNAMBUCO E PARAÍBA \\ E OS NEGÓCIOS DA CHINA (1759-1783)
}

Thiago Alves Dias ${ }^{1}$

$\mathrm{E}$

$\mathrm{m}$ artigo recentemente publicado, os historiadores J. Bohorquez e M. Menz, reiterando as considerações de uma série de outros pesquisadores, chamaram a atenção da comunidade acadêmica sobre os problemas historiográficos oriundos da interpretação bilateral (Brasil-África) para a interpretação do negócio negreiro no Império Português. Atestaram com pesquisa empírica de fôlego a participação e pujante relevância dos negociantes portugueses no tráfico de escravos. Sem retomar os antigos esquemas triangulares, mas, antes de tudo, propondo saídas críveis e criativas, os historiadores chegaram à conclusão de que o comércio de escravos prescindia de dezenas de transações mercantis, dentre elas, os negócios de têxteis indianos, a dispersão de capital, grandes investimentos estrangeiros e transações com o Brasil, no caso do comércio com os portugueses. ${ }^{2}$

Este artigo se filia a essa proposta historiográfica renovada que busca recolocar questões sobre os negociantes do Império Português, encontrando outras interpretações para além do comércio triangular e bilateral.

1 Doutor em História Econômica, Universidade Federal do Rio Grande do Norte (UFRN). dias. thiagoa@gmail.com.

2 Jesus Bohorquez e Maximiliano Menz, "State contractors and global brokers: the itinerary of two Lisbon merchants and the transatlantic slave trade during the eighteenth century", Itin"'Thiago Alves Dias" Bohorquez Menzerario, v. 42, n. 3 (2018), pp. 403-429: https://doi. org/10.1017/S0165115318000608. 
Para tanto, partiremos da história da Companhia Geral de Comércio de Pernambuco e Paraíba (CGPP), analisando alguns aspectos particulares da formação, funcionamento e longo processo de liquidação da CGPP, fundada em 1759, que operou entre 1760 e 1780 em regime de monopólio comercial no Norte do Estado do Brasil com negócios em escala global.

A problemática de pesquisa aqui empreendida diz da formação do capital acionista da Companhia em Portugal e no Brasil; seu impacto no cenário mercantil no Norte do Estado do Brasil, ou seja, na área monopolizada; e algumas negociações em dimensões e escalas diferentes: na região, no Atlântico e na Europa, atentando para as formas e os ganhos tanto da Companhia, globalmente, como de seus respectivos sócios, individualmente. Por fim, demonstraremos que, depois de 1780, mesmo com a perda do monopólio na região, a Companhia não deixou de existir, tendo atuado na cobrança de dívidas dos negociantes no Norte do Estado do Brasil, assim como na realização de negócios, com capitais próprios, oriundos das negociações coloniais, como foi o caso de sua primeira viagem para a China. ${ }^{3}$

Nossa proposta analítica se filia às conclusões propostas por $\mathrm{J}$. Bohorquez e M. Menz quando da análise da trajetória de negociantes de escravos portugueses: os grandes e bem-sucedidos negócios setecentistas do Império Português estavam relacionadas à Coroa portuguesa e requeriam pluralidade de negócios em praças mercantis na Europa, América, África e Ásia. Além disso, demandavam alta dispersão de capital; grandes investimentos estrangeiros; liquidação e negociações nas diversas praças; e a participação efetiva de negociantes portugueses.

\section{Os ajustes institucionais e o início das negociações}

O texto "Razões políticas pelas quais as Companhias Gerais do Comércio se julgam úteis e necessárias no Reino de Portugal”, escrito em 1755 por

3 Fernando Novais, Portugal e Brasil na crise do Antigo Sistema Colonial (1777-1808), $9^{\mathrm{a}}$ ed., São Paulo: Hucitec, 2011, pp. 190-191; Frédéric Mauro, "Merchant communities, 1350-1750", in James Tracy (dir.), The Rise of Merchant Empires: Long-distance Trade in the Early Modern World, 1350-1750 (Cambridge: Cambridge University Press, 1993), pp. 255-286; Sheilagh Ogilvie, Institutions and European trade: Merchant guilds, 1000-1800, Cambridge: Cambridge University Press, 2011, pp. 414-434; Philip T. Hoffman, "What do States do? Politics and Economic History” The Journal of Economic History, v. 75, n. 2 (2015), pp. 303-332. 
Francisco Xavier de Mendonça Furtado, irmão do Marquês de Pombal, quando este ainda se encontrava nas missões demarcatórias de fronteiras e de erguimento de fortificações no Estado do Grão-Pará e Maranhão, apresenta diversas justificativas para a criação de companhias monopolistas de comércio no Brasil. Francisco Xavier defende o projeto de estabelecimento de quatro companhias para as principais praças mercantis do Brasil. O principal objetivo dessas companhias era regular o comércio colonial em benefício de um grupo mais reduzido de mercadores. Uma vez estabelecidas, elas iriam comandar a compra e o envio de produtos europeus para o Brasil, com preferência para os produtos nacionais, incentivando assim a indústria portuguesa. Entre outros aspectos que seriam regulados pelas companhias, Francisco Xavier previa que os preços dos produtos vendidos no Brasil seriam acrescidos de, pelo menos, $45 \%$ em cima dos preços adquiridos, cobrindo assim custos como: fretes, emolumentos, taxas e as comissões de negociação para a Companhia. ${ }^{4}$

Em 1755, o processo de fundação da Companhia Geral do Grão-Pará e Maranhão, a primeira das quatro companhias monopolistas defendidas por Francisco Xavier, provocou debates sobre o tema e manifestações contrárias ao projeto. Os homens de negócio lusitanos, organizados em torno da Mesa do Espírito Santo da Pedreira, uma antiga irmandade ou confraria fundada no século XV que assumiu o papel institucional de representar junto à Coroa os homens de negócio, apresentaram um extenso documento intitulado "Representação feita pelos deputados da Mesa do Espirito Santo dos Homens de Negócio de Lisboa contra a instituição da Companhia Geral de Comércio do Grão-Pará e Maranhão".5 As críticas

4 Francisco Xavier de Mendonça Furtado, Razões políticas pelas quais as Companhias Gerais do Comércio se julgam úteis e necessárias no Reino de Portugal, Pará, 1755, Manuscrito, Arquivo Histórico Ultramarino (AHU), cx. 39, doc. 3.674; Arnaldo António Pereira, "Para uma caracterização da política colonial pombalina: a administração de Francisco Xavier de Mendonça Furtado no Estado do Grão-Pará e Maranhão (1752-1759)", in Actas das Primeiras Jornadas de História Moderna (Lisboa: Centro de História da Universidade de Lisboa, 1986), v. 2, pp. 1075-1095.

5 Eulália Maria Lahmeyer Lobo, "Alguns aspectos da história da Mesa do Bem Comum dos Mercadores: Séc. XVII e XVIII”, V Colóquio Internacional de Estudos Luso-Brasileiros, Coimbra, 1965; Jorge Miguel Viana Pedreira, "Os homens de negócio da Praça de Lisboa de Pombal ao Vintismo (1755-1822): diferenciação, reprodução e identificação de um grupo social" (Tese de Doutorado, Universidade Nova de Lisboa, 1995), pp. 60-68; João Lúcio de Azevedo, Estudos de história paraense, Pará: Typ. de Tavares Cardoso, 1893, p. 55. 
inicialmente vieram por aforismos: "a ruína do comércio na justa ponderação de um estanco, ou monopólio"; "os interesses reduzidos ao particular"; "enriquecidos poucos para empobrecerem muitos" e "o estanco geral é nocivo aos povos, a falta de liberdade destrutiva do mesmo comércio". ${ }^{6}$

O ponto alto do documento, ao nosso ver, está no argumento da incompatibilidade da Companhia nas próprias colônias. Afinal, "nos países estranhos verdade é, que por meio das Companhias tem subido o negócio aos mais avultados lucros: mas não se assinará companhia com exercício de vassalos para vassalos, e de domínios para domínios, e os vassalos todos estão sujeitos ao mesmo príncipe". Lembravam ainda que a Inglaterra e a Holanda tinham "grandes e avultadas companhias, mas essas Companhias não se dirigem aos domínios de Inglaterra ou Holanda, [mas] buscam diversos países onde o comércio floresce, extraindo forças alheias sem debilitar as próprias".?

As companhias fundadas pelo marquês, inclusive a CGPP, foram pensadas para operar através de certos elementos inovadores e inéditos na história das companhias de comércio europeias, particularmente as portuguesas, tais como: largos créditos para o financiamento da produção e da aquisição de escravatura e fomento à produção agrícola de novos produtos. Esses novos aspectos podem ser observados, simbolicamente, no fato de a nomenclatura das companhias coloniais (Grão-Pará e Maranhão, Pernambuco e Paraíba) e das metropolitanas (Douro e Algarve) conter o termo "geral". Na nomenclatura de uma companhia portuguesa, o termo "geral" se fez presente pela primeira vez na pioneira Companhia fundada para o Brasil, em 1649, a qual, se não detinha ambições parecidas, em alguns aspectos se aproximava das que seriam estabelecidas posteriormente: reestruturar a produção do açúcar a partir de créditos e

6 "Representação feita pelos Deputados da Mesa do Espirito Santo dos Homens de Negócio de Lisboa contra a instituição da Companhia Geral de Comércio do Grão-Pará e Maranhão, 1755", in António Carreira, As companhias pombalinas de navegação, comércio e tráfico de escravos entre a costa africana e o Nordeste Brasileiro (Bissau: Centro de Estudos da Guiné Portuguesa, 1969), pp. 373-403. Ver também: Companhia Geral do Grão-Pará e Maranhão, Instituição da Companhia Geral do Grão Pará e Maranhão, Lisboa: Officina de Miguel Rodrigues, 1755; Manuel Nunes Dias, “A Companhia Geral do Grão-Pará e Maranhão", Revista de História, v. 37 (1971); Antônio Carreira, A Companhia Geral do Grão-Pará e Maranhão, São Paulo: Companhia Editora Nacional, 1988, 2 v. 
do comércio de mercadorias sob controle dos portugueses e, com a retomada do comércio do açúcar, financiar as guerras de restauração da região contra o domínio holandês. Nesse sentido, essas companhias não visavam somente o comércio, ou seja, a circulação, mas também previam financiamentos e fomento produtivo.

Seguimos, portanto, a pista enunciada por Jorge Borges de Macedo, para quem as companhias só são compreendidas quando ligadas a uma "organização geral do comércio e a uma garantia de mercados". 8 Acrescentamos ao argumento a questão do crédito e fomento à produção. Esses aspectos das companhias coloniais foram recentemente rediscutidos por Kenneth Pomeranz e Robert Brenner, por exemplo, reiterando algumas proposituras já defendidas por estudiosos clássicos do tema, para quem as companhias comerciais coloniais poderiam ter contribuído para o crescimento europeu por estarem bem organizadas e não competirem com os imitadores nacionais dos seus produtos. ${ }^{9}$

De acordo com João Lúcio de Azevedo, o documento enviado pelos homens de negócio de Lisboa contra a Companhia irritou Sebastião José de Carvalho e Melo por ter exposto "todos os sofismas econômicos, todas as previsões erradas, todos os danos prováveis, que o exame dos prolixos estatutos facilmente deixava adivinhar" da Companhia. ${ }^{10} \mathrm{~A}$ resposta veio rápido e em poucos dias D. José I aboliu a Mesa dos Homens de Negócio, alegando que alguns negociantes "empregavam maliciosamente" seus abusos, "arruinando inadvertidamente o comércio geral". ${ }^{11}$

8 José Borges de Macedo, "Companhias de comércio", in Joel Serrão (dir.), Dicionário de história de Portugal: Vol. 2: C-F (Porto: Figueirinhas, 1965), pp. 122-130.

9 Kenneth Pomeranz, A grande divergência: a China, a Europa e a construção da economia mundial moderna, Lisboa: Edições 70, 2013, p. 326; Robert Brenner, Merchants and Revolution: Commercial Change, Political Conflict, and London's Overseas Traders, 1550-1653, London: Verso, 2013; Manuel Nunes Dias, "Companhias versus companhias na competição colonial”, Revista Portuguesa de História, v. 16 (1978).

10 Azevedo, Estudos de história paraense, p. 57.

11 "Alvará que aboliu a Confraria do Espirito Santo da Pedreira: Lisboa, 30 de setembro de 1755", in Antônio Delgado da Silva, Collecção da Legislação Portuguesa, 1750-1762 (Lisboa: Typ. Maigrense, 1830), p. 396-397. Sobre o assunto, ver também: João Lúcio de Azevedo, O Marquês de Pombal e sua época, Rio de Janeiro: Annuario do Brasil, 1922, pp. 136-140; Francisco José Calazans Falcon, "A prática mercantilista em Portugal durante a época moderna: papel-chave da Junta do Comércio", Revista de História da Universidade Severino Sombra, v. 1, n. 1 (2002), pp. 5-27; A época pombalina: política econômica e monarquia ilustrada, São Paulo: Ática, 1982, pp. 311-316. 
Além disso, os homens de negócio que assinaram o documento foram perseguidos, alguns degredados e outros presos.

Francisco Xavier de Mendonça Furtado defendeu o crescimento da indústria nacional através do domínio do comércio colonial nas mãos de uma companhia acionista, já que isso permitiria que os mesmos homens envolvidos na Companhia lucrassem com o estabelecimento de indústrias para abastecer o comércio colonial. Por outro lado, alguns homens de negócio contra-argumentaram, baseados no monopólio que estaria reservado para os que detinham capital suficiente para serem acionistas da Companhia. Nem o projeto de Francisco Xavier se concretizou na plenitude, nem, tampouco, os contrários à Companhia estavam corretos em suas previsões.

A fundação e funcionamento da Companhia Geral do Grão-Pará e Maranhão a partir de 1755 suscitou diversos projetos para a criação das mais variadas companhias. Por exemplo, a partir de 1757 foram enviadas ao Conselho Ultramarino variadas cartas e requerimentos dos homens de negócios, senhores de engenho, lavradores de cana, fazendeiros e curtidores de couro para a fundação de companhias de comércio a partir da praça do Recife. Pelo menos três companhias diferentes foram solicitadas a D. José I a partir da Câmara do Recife - uma para resgate de escravos na África, outra para a exploração de salitre e possíveis metais preciosos na região dos Cariris (sertão entre o Rio Grande do Norte e o Ceará) e uma terceira para exploração das carnes secas do sertão das Ribeiras do Piranhas-Açu e Jaguaribe - nenhuma foi atendida, pelo menos da forma que queriam os colonos. ${ }^{12}$

Por outro lado, foi bem sucedida a iniciativa, impulsionada pelo futuro Marquês de Pombal, de alguns dos grandes negociantes lisboetas - tais como José Rodrigues Bandeira, primeiro provedor da Junta do Comércio fundada em 1755; Inácio Pedro Quintela, envolvido em diversos contratos e estancos no Brasil, como o da pesca da baleia; Policarpo José Machado e Anselmo José da Cruz, investidores em negócios rentáveis

12 Sobre as muitas solicitações para companhias de comércio em Pernambuco, ver: José Ribeiro Júnior, Colonização e monopólio no Nordeste brasileiro: a Companhia Geral de Pernambuco e Paraíba, 1759-1780, São Paulo: Hucitec, 1976, pp. 74-81; Érika Simone de Almeida Carlos Dias, “'As pessoas mais distintas em qualidade e negócio': elites, relações políticas e a Companhia de Comércio em Pernambuco na segunda metade de setecentos" (Tese de Doutorado, Universidade Nova de Lisboa, 2014), pp. 135-137. 
como o tabaco, diamantes e escravos, só para citar alguns - que levaram ao rei D. José I o projeto da CGPP, em $1759 .^{13}$

A Companhia se propunha a realizar investimentos na região, ampliando a produção dos gêneros coloniais tradicionais e incentivando a produção de novos, e para tanto ela deveria garantir o fornecimento de escravos e o crédito necessário para os produtores da região. A contrapartida do projetado desenvolvimento econômico da região seria "o comércio exclusivo das duas capitanias de Pernambuco e Paraíba com todos os seus Distritos" por vinte anos. ${ }^{14}$ Dessa forma, somente a Companhia poderia levar ou trazer mercadorias, gêneros e frutos da Europa para o norte do Estado do Brasil e vice-versa, e também para as demais capitanias do Brasil. O comércio interior na região continuaria a operar como de costume.

Em agosto do mesmo ano, o rei aprovou a instituição da CGPP, instituindo os símbolos e motivos para representar a nova instituição mercantil. ${ }^{15}$ Assim, sob o signo de uma estrela que representa a fonte de luz, associada a renascimento, seguido dos dizeres em latim, tributados ao evangelista Mateus, "Ut luceat omnibus" - ou seja, "que ilumine a todos", como já havia afirmado o Pe. Antônio Vieira em um dos seus sermões - associado a uma imagem de Santo Antônio, foi instituída a nova Companhia. Santo Antônio seria o "santo que depara as coisas perdidas", padroeiro de Portugal, que figura no nome original da Vila de Santo Antônio do Recife e que, em 1203, em Pádua, depois de viajar

13 Pedreira, Os homens de negócio; Carlos Guimarães da Cunha, Negociantes, mercadores e traficantes no final da monarquia absoluta: a burguesia mercantil em Portugal, dos anos finais do século XVIII até o início da Revolução Liberal, Lisboa: Colibri, 2014; José Capela, As burguesias portuguesas e a abolição do tráfico da escravatura, 1810-1842, Porto: Afrontamento, 1987, p. 22-24; Fernando Dores Costa, "Capitalistas e serviços: empréstimos, contratos e mercês no final do século XVIII”, Análise Social, v. 27, n. 116-117 (1992), pp. 441-460; Maria do Rosário Castiço de Campos, "A fábrica de papel de Lousã e o processo de industrialização de Portugal", História: Revista da Faculdade de Letras da Universidade do Porto, v. 10 (2009), pp. 145-150; Alexandre Vieira Ribeiro, "O comércio das almas e a obtenção de prestigio social: traficantes de escravos na Bahia ao longo do século XVIII”, Locus: Revista de História, v. 12, n. 2 (2006), p. 9-27; Manuel Benavente Rodrigues, "Os homens do Erário Régio", Pecvnia, n. 13 (2011), pp. 59-81; Nuno Luís Madureira. Mercado e privilégios. A indústria portuguesa entre $1750 \mathrm{e}$ 1834. Lisboa: Editorial Estampa, 1997, p. 83-98.

14 Instituição da Companhia Geral de Pernambuco e Paraíba, Lisboa: Officina de Miguel Rodrigues, 1759, p. 15.

15 Instituição da Companhia Geral de Pernambuco e Paraíba, Lisboa: Officina de Miguel Rodrigues, 1759, p. 15. 
pregando em diversos reinos, fez com que as lojas dos "mercadores e vendeiros [...], e ninguém trabalhava até que tornavam da pregação". Foi esse santo, portanto, escolhido como padroeiro da Companhia. ${ }^{16}$

Figura 1 - Mapa da carga de que se assinaram conhecimentos para Lisboa, 1769

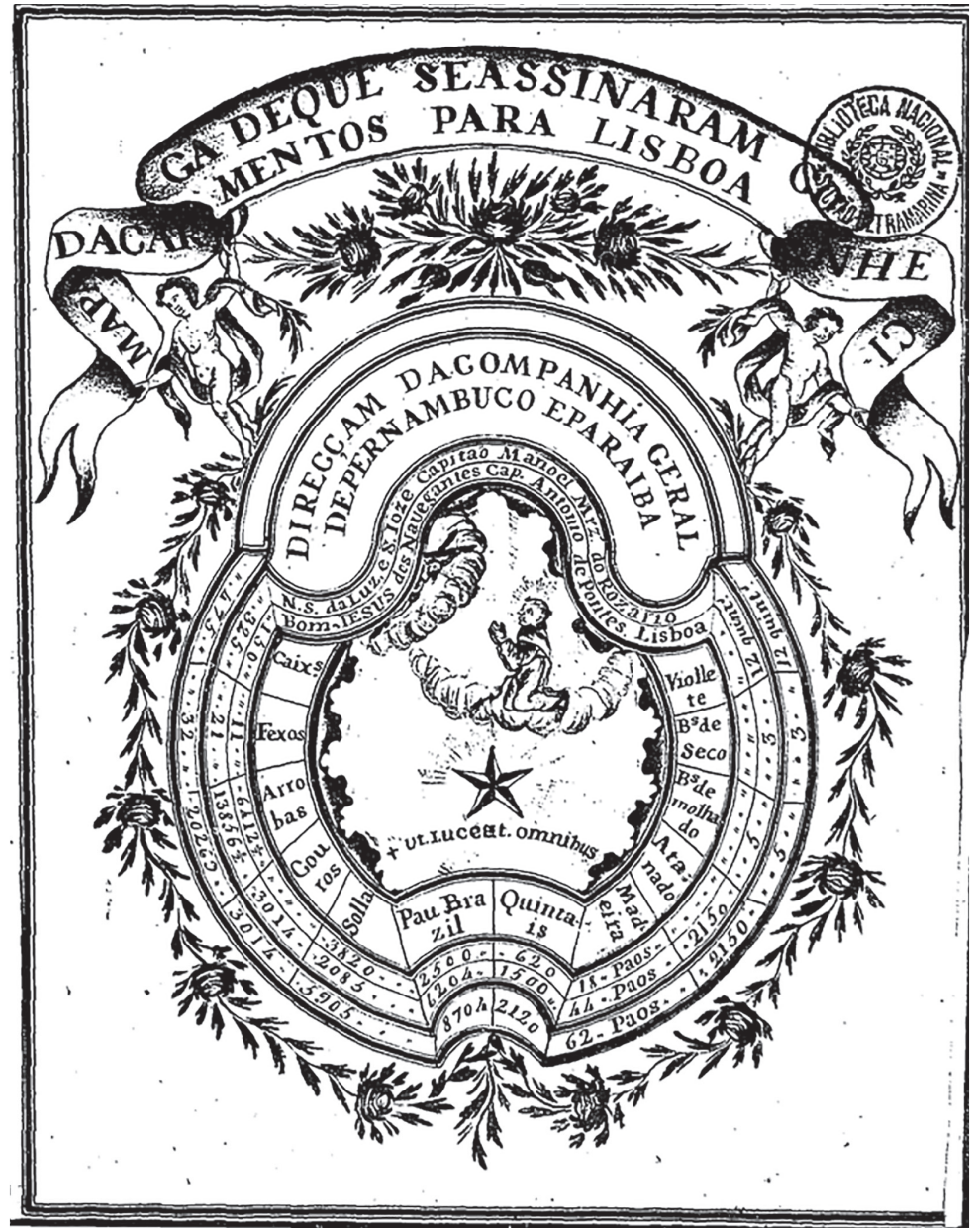

Fonte: Arquivo Histórico Ultramarino (AHU), Pernambuco, cx. 106, doc. 8.238.

16 "Neque accendunt lucernam, et ponunt eam sub modio, sed super candelabrum, ut luceat omnibus, qui in domo sunt" ou "Nem se acende a candeia e se coloca debaixo do alqueire, mas no velador, e dá luz a todos, que estão na casa" (Mateus 5, 15). Antonio Vieira, "Sermão de Santo Antônio, 1657", in Antônio Vieira, Sermões: Vol. XII, Erechim: Edelbra, 1998; Diogo do Rosário, Flos Sanctorum: história das vidas dos cristões, Lisboa: Antonio Craesbeeck de Mello, 1681, p. 531. 
Aprovado o projeto, era preciso reunir o fundo mínimo necessário, estimado em 3.400 .000 cruzados, distribuídos em 3.400 ações no valor de mil cruzados cada uma. Fosse em dinheiro, produtos coloniais ou em barcos, "em troca de sua entrada o sócio recebia um título negociável que tomava o nome de ação" ${ }^{17} \mathrm{O}$ período destinado para a compra das ações foi de três meses para Portugal continental, seis meses para as ilhas e de um ano para toda a América portuguesa.

As questões concernentes a compra e venda de ações, depois do início do funcionamento da Companhia, foram reguladas e documentadas em livros específicos e estiveram relacionadas à venda inicial, ou seja, as cessões de apólice para vendas ou mudança de titular das ações que transcorreram durante os vinte anos de funcionamento da Companhia se davam em função dessa venda inicial. ${ }^{18}$ No norte do Estado do Brasil, o então governador de Pernambuco Luís Diogo Lobo da Silva fez circular, em dezembro de 1759, um bando convocando os interessados em adquirirem as ações da Companhia. ${ }^{19}$

Ao serem integralizadas as vendas totais das ações iniciais, o que ocorreu somente por volta de 1763, Ribeiro Júnior chegou ao seguinte quadro analítico: 429 sócios adquiriram as 3.400 ações, formando o capital social originário da Companhia. Negociantes, senhores de engenho, lavradores e curtidores de sola no norte do Estado do Brasil adquiriram 329 ações, sendo 303 em Pernambuco, distribuídas entre, pelo menos, 22 pessoas. As demais 26 ações provavelmente foram adquiridas por

17 Rui Manuel Figueiredo Marcos, “As companhias pombalinas: contributo para a história das sociedades por acções em Portugal” (Tese de Doutorado, Universidade de Coimbra, 1997), p. $431 ; 456$.

18 Por exemplo: as ações $\mathrm{n}^{\mathrm{o}} 300$ a 306 e 1.745 a 1.747, totalizando nove, foram adquiridas entre 1759 e 1760 pelo negociante de couros de Recife Luís da Costa Monteiro. Quando do seu falecimento, as mesmas nove ações, com as mesmas numerações, foram transferidas para seu filho, Domingos da Costa Monteiro. Cessões de Apólice nº 300 a 306 e 1.745 a 1.747, Lisboa, 28/08/1769, Manuscrito, Arquivo Nacional da Torre do Tombo (ANTT), Companhia Geral de Pernambuco e Paraíba (CGPP), Livro Primeiro de Cessões, liv. 327, p. 157v.

19 Registro de um bando que mandou lançar nesta Capitania o Ilmo. Ex. Sr. Governador e Capitão General Luís Diogo da Silva, General dessas Capitanias sobre a entrada da Companhia de Negócio que sua Majestade manda na forma estabelecida no Grão-Pará e Maranhão, Natal, 20/12/1759, Manuscrito, Instituto Histórico e Geográfico do Rio Grande do Norte (IHGRN), Registro de Cartas e Provisões do Senado da Câmara de Natal (RCPSCN), cx. 3, liv. 10, pp. 153-153v; Fernanda Olival, "O Brasil, as companhias pombalinas e a nobilitação no terceiro quartel de Setecentos”, Anais da Universidade de Évora, n. 8-9 (1998-1999), pp. 73-97. 
negociantes de tabaco das Alagoas, senhores de engenho da Paraíba ou homens de negócio do Rio de Janeiro e Maranhão. Na Bahia e Angola foram adquiridas 3\% das ações, enquanto os negociantes do Porto adquiram 17\%. Quase 2.500 ações, ou seja, mais de 70\% do capital inicial da Companhia, adveio de sócios da praça de Lisboa, o que não significou ser somente capital português. ${ }^{20}$

De acordo com os "Estatutos Particulares ou Diretório Econômico" da nova empresa, logo que os cargos administrativos da Companhia fossem devidamente preenchidos, a Junta em Lisboa deveria "chamar os Capitães dos navios e ouvindo-os sobre o tempo competente para a partida das frotas e dos navios soltos para qualquer porto, se tomará assento sobre cada uma das expedições". A Junta deveria se aconselhar sobre as fazendas que deveria carregar nos navios, suas quantidades, qualidades e distribuição entre as naus, e todas as referidas fazendas teriam que estar munidas das respectivas contas de custo, "com toda a formalidade, especificação necessária de números, medidas, pesos, para se lançarem e transcreverem nos livros de entrada". ${ }^{21}$

O início e o término do funcionamento do monopólio da Companhia foram estabelecidos em função do tempo das frotas, ou seja, as viagens anuais entre a Europa e o Brasil. A primeira frota saiu de Lisboa em 1760 levando gêneros secos e molhados, avaliados em 208:860\$000 e marcou o início das operações da Companhia. Como, até aquele momento, o capital inicial estipulado para o início das operações não estava integralizado, a solução para suprir a falta de recursos foi contar com empréstimos e recursos variados fornecidos pela Coroa. ${ }^{22}$ Além de dinheiro do Depósito do Reino, a CGPP recebeu empréstimos de litígios judiciais oriundos da Junta do Comércio, como foi o caso de 6 contos de réis pertencentes a uma das sociedades mercantis de Feliciano Velho

20 Ribeiro Júnior, Colonização e monopólio no Nordeste brasileiro, p. 94. A lista dos sócios originários utilizada nesse estudo foi gentilmente cedida por Angélica Vasconcelos.

21 Estatutos Particulares ou Directório Económico para o governo interior da Companhia Geral de Pernambuco e Paraíba, Lisboa: Officina de Miguel Rodrigues, 1760, p. 7.

22 José Mendes da Cunha Saraiva, Companhia Geral de Pernambuco e Paraíba, Lisboa: Arquivo Histórico do Ministério das Finanças, 1941, p. 13; Lúcia Lima Rodrigues e Alan Sangster, “"Public-private partnerships": the Portuguese General Company of Pernambuco and Paraíba (1759)", Business History, v. 54, n. 7 (2012), pp. 1142-1165. 
Oldemberg e Daniel Gilmestre, que operavam na Ásia a partir de Lisboa, com diamantes do Brasil e outro produtos, na primeira companhia monopolista criada pelo marquês, a Companhia do Comércio da Ásia Portuguesa. ${ }^{23}$ Esses realocamentos de capitais por parte da Coroa, disponibilidade da estrutura burocrática e dos equipamentos mercantes e náuticos, como armazéns e navios, tende a demonstrar não somente o interesse do próprio Estado português no funcionamento da Companhia, como também os níveis de envolvimento dos interesses da Coroa dentro da estrutura e funcionamento de uma companhia formada por agremiação de negociantes.

Uma Junta Administrativa em Lisboa, uma Direção no Porto e outra em Recife. Com o adensamento dos negócios e ampliação dos mercados, o patrimônio institucional foi acrescido de navios, armazéns e trapiches; procuradores, correspondentes, informantes e sócios em várias praças mercantis nas quatro partes do mundo; além de um sem-número de equipamentos necessários ao pleno funcionamento da Companhia. Em novembro de 1759, a Junta em Lisboa escreveu sua primeira carta para a Direção em Recife, anunciando as diretrizes institucionais da Companhia para a realização de suas primeiras negociações com a frota que aportaria no ano seguinte.

As primeiras negociações da Companhia, realizadas no final de 1759 para o envio da frota no primeiro semestre de 1760 para Recife, contaram somente com capitais da Coroa e dos acionistas de Lisboa e Porto. Com a carregação seguiram as primeiras contas de venda já com os valores que deveriam ser vendidos, ou seja, acrescidos de $45 \%$ sobre o preço dos produtos adquiridos. Para a frota de torna viagem, a Direção em Recife deveria ter os mesmos cuidados para com a escrituração mercantil dos açúcares, madeiras, couros e demais produtos adquiridos. A Junta também especificou nessa primeira carta questões relacionadas ao "negócio da Costa da África". Recomendou que a Direção fizesse "particular estudo em ver os gêneros que se podem melhor adaptar ao

23 Aviso da Secretária da Junta do Comércio para a Junta da Companhia Geral de Pernambuco e Paraíba, Lisboa, 10/11/1768, Manuscrito, ANTT, Junta do Comércio, liv. 112, p. 31; Tij1 Vannest, Global Trade and Commercial Networks: Eighteenth-Century Diamonds Merchants, London: Pickering \& Chatto, 2011. 
dito negócio da África, e em fazer experiência de preparar o tabaco pelo modo que ali mais se estima", indicando buscar na Bahia um mestre para ensinar "a preparar o dito gênero, do mesmo modo como se prepara na Bahia". O documento também anunciou as obrigações da Direção para favorecer o cultivo e o fomento de novos produtos, incluindo o algodão e outras drogas, enquanto "gêneros muito consideráveis e dignos de promover a cultura deles". ${ }^{24}$

Constituída a Direção em Pernambuco e expedida a primeira frota em abril de 1760, era necessário continuar a ampliação das negociações da Companhia. Já instituída de seu monopólio comercial na região, as primeiras negociações foram pautadas no conhecimento dos negociantes acionistas e nos seus negócios particulares outrora realizados. Constava no carregamento da Companhia, e em meio ao montante geral de remessas para a venda avulsa, quantidades de boticas particulares, um caixote para João da Costa Monteiro Júnior, sobrinho do sócio e curtidor de sola, Luís da Costa Monteiro, além de barricas de farinha de trigo previamente negociadas. ${ }^{25} \mathrm{O}$ que queremos demonstrar com esses exemplos é que de fato a Companhia instaurou seu monopólio ao açambarcar tanto as vendas avulsas dos gêneros na região como algumas negociações antes realizadas por particulares que, a partir daquele momento, passaram para ela.

O segundo passo foi ampliar as praças de negociação e o negócio mais rentável logo foi instituído. A Companhia do Grão-Pará e Maranhão atuou na rota de Angola somente entre sua fundação e o início do funcionamento da CGPP, quando a escravatura de Angola passou a ser exclusividade desta, levando-a ao status de "maior exportadora individual de escravos em Luanda no período enquanto durou o monopólio". ${ }^{26}$

O primeiro administrador da Companhia do Grão-Pará e Maranhão em Angola passou a ser o administrador da CGPP a partir de 1760. Foi

24 "Carta da Junta da Companhia de Comércio de Pernambuco e Paraíba para Direção de Pernambuco, Lisboa, 24/11/1759", in Saraiva, Companhia Geral de Pernambuco e Paraíba, pp. 19-22.

25 "Instruções de compra e venda seguidas na primeira frota expedida pela Junta da Companhia para Pernambuco, Lisboa, 04/04/1760", in Saraiva, Companhia Geral de Pernambuco e Paraíba, pp. 22-27.

26 Maximiliano M. Menz, “A Companhia de Pernambuco e Paraíba e o funcionamento do tráfico de escravos em Angola (1759-1775/1780)", Afro-Ásia, vol. 48, 2013, p. 54. 
o negociante "experimentado nos cálculos e projetos mercantis" Raimundo Jalamá, que já se encontrava em Luanda em 1760, seguido do administrador Francisco Bruno de Lemos. Fez parte dessa primeira administração um caixeiro chamado Alexandre José de S. Maria, que foi na primeira nau enviada para a África com uma carregação de 17:642\$499, a ser "reduzida a escravatura" para logo ser remetida a Recife. A partir daquele ano, qualquer navegação para Angola oriunda do norte do Estado do Brasil deveria ser encaminhada aos cuidados dos administradores da Companhia em Angola. ${ }^{27}$

No segundo semestre de 1760, a Junta já havia instituído seus procuradores em todas as principais praças mercantes do Brasil: no Rio de Janeiro, os negociantes Manoel Rodrigues Ferreira, Manoel Rodrigues de Freitas Silva e Francisco Pinheiro Guimarães; na Bahia, Joaquim Ignácio da Cruz, Antônio Cardoso dos Santos e Luiz Coelho Ferreira; e no Pará e Maranhão, a própria Direção da Companhia Geral que ali já estava instalada.

O funcionamento conjunto das companhias pombalinas, pelo menos em alguns aspectos, pode ser percebido na escolha dos procuradores da CGPP nas praças europeias, assim como foi em Angola. Domingos Luiz da Costa, negociante português com casa comercial em Amsterdã, negociava amarras, correntes, cabos para ancoragem e enxárcias para mastros de navio para a Companhia Geral do Grão-Pará e Maranhão e, por esse motivo, foi escolhido para ser também um dos primeiros parceiros mercantis da CGPP nos Países Baixos. O mesmo se deu com Geraldo Braancamp, que também possuía uma casa comercial em Amsterdã. Em 1762, a Junta em Lisboa escreveu a ele afirmando que "a pública fama", ou seja, a confiança e status que possuía o negociante e sua casa, havia chegado a seu conhecimento, além de "as vantajosas informações que do seu zelo nos deu o Sr. José Francisco da Cruz nosso companheiro e vice-provedor desta Junta são motivos assaz fortes, para muito desejar-

27 Luiz Antonio de Oliveira Mendes, "Discurso acadêmico ao programa das Memórias Econômicas da Academia Real de Ciências, 1793", in Memórias Econômicas da Academia Real das Ciências de Lisboa (Lisboa: Typografia da Academia, 1812), tomo 4, p. 37; Carreira, A Companhia Geral do Grão-Pará e Maranhão, v. 1, p. 243; Carta da Junta da Companhia para Raimundo Jalamá e Francisco Bruno de Lemos em Angola, Lisboa, 08/08/1760, Manuscrito, ANTT, CGPP, Livro Copiador de Cartas de Angola, liv. 290. 
mos a sua estimável correspondência, com o mesmo desvelo que serviu a Companhia do Maranhão". ${ }^{28} \mathrm{Na}$ ocasião, a CGPP encomendou a Geraldo Braancamp lona de Holanda, lona de Moscovia, barris de alcatrão da Suécia, gurupés.

A primeira compra da Companhia em San Sebastián, cidade do País Basco espanhol que foi sede de uma das mais notáveis companhias de comércio espanhol, a Real Compañia Guipuszcoana de Caracas, fundada em 1728, se deu através de negociações com o comerciante basco D. Juan de Carrera. ${ }^{29}$ Também pela reputação e confiança e "ainda em particular informação que temos dos senhores da Companhia do Maranhão, fez resolver essa Junta a procurar também sua estimada correspondência". A encomenda realizada pela CGPP foi de 44 âncoras que seriam pagas com letras sacadas sobre Geraldo Braancamp. ${ }^{30}$ Para a Tierney and Lylly Company, em Londres, a CGPP encomendou peças de ferro de artilharia para bateria dos navios. ${ }^{31}$ Tudo nesses primeiros anos de atuação e expansão.

Ao passo que a Companhia delegou seus procuradores nas praças do Brasil e de Angola, também foi paulatinamente delegando seus agentes na Europa, utilizando-se dos contatos e correspondentes de confiança da outrora fundada Companhia Geral do Grão-Pará e Maranhão. Os ajustes institucionais necessários a uma companhia comercial dessa envergadura exigiram interlocutores distribuídos pelas principais praças mercantis.

No norte do Estado do Brasil os ajustes para o início do funcionamento da Companhia foram marcados por conflitos e disputas entre os negociantes, senhores de engenho e as autoridades da Coroa portuguesa na região, ${ }^{32}$ no entanto, a Companhia foi implacável na sua atuação

28 Carta da Junta da Companhia para Domingos Luiz da Costa em Amsterdã, Lisboa, 31/03/1761, Carta da Junta da Companhia para Geraldo Braancamp em Amsterdã, Lisboa, 09/02/1762, Manuscrito, ANTT, CGPP, Livro Copiador de Itália e Norte, liv. 288.

29 Raquel Rico Linage, Las reales compañias de comercio con América: los órganos de gobierno, Sevilla: Escuela de Estudios Hispano-Americanos de Sevilla, 1983, p. 265-277.

30 Carta da Junta da Companhia para Don Juan de Carrera em San Sebastián, Lisboa, 12/03/1763, Manuscrito, ANTT, CGPP, Livro Copiador de Itália e Norte, liv. 288.

31 Carta da Junta da Companhia para Tierney e Lylly em Londres, Lisboa, 21/01/1765, Manuscrito, ANTT, CGPP, Livro Copiador de Itália e Norte, liv. 288.

32 "Carta da Direção da Companhia em Pernambuco para a Junta em Lisboa, Recife, 30/06/1760", in Saraiva, Companhia Geral de Pernambuco e Paraiba, pp. 28-37. 
enquanto empresa monopolista e de metas a serem alcançadas, tanto no movimento global de suas atividades quanto no lucro de seus sócios. ${ }^{33}$

\section{O giro do capital}

O negociante português Manuel Joaquim Rebelo, acionista da Companhia Geral do Grão-Pará e Maranhão, narrou em 1795 como funcionava o giro do capital a partir da alegoria de uma máquina de várias rodas. Uma vez que as rodas estivessem "dispostas com tal arte, que à proporção que se vai reforçando o movimento da roda maior, se vai gradualmente acelerando mais o das rodas menores". ${ }^{34}$ Rebelo pontuou que a roda maior era o dinheiro, já as inferiores eram o trabalho, a indústria, a lavoura, as artes e o comércio. No caso da CGPP, dinheiro foi quase sinônimo de crédito e, portanto, a roda do crédito é que possibilitou o principiar das negociações.

Importante mecanismo creditício estabelecido pela Companhia foi o crédito de capitais direto para montagem, aquisição ou melhoria para o negócio do açúcar e do algodão. Fosse para ampliação de engenhos ou aquisição de carros de boi e caixas, a CGPP desenvolveu uma linha de crédito direto ao produtor. De acordo com as próprias diligências da Junta, os empréstimos aos lavradores e senhores de engenho "não foram ordenadas pela Lei da Instituição, mas sim disposta por esta Junta a imitação do que pratica por Instituto a Companhia Geral da Agricultura das Vinhas do Alto Douro, isto é, em beneficio da agricultura dessas Capitanias". ${ }^{35}$ Sendo assim, por emulação de mais uma das práticas de

33 "Exame e resposta aos fundamentos da representação que os homens de negócio da praça desta cidade fizeram a sua majestade para a extinção da Companhia Geral do Grão-Pará e Maranhão que poderá servir para a decisão desta importante matéria, Pará, s.d., in Carreira, $A$ Companhia Geral do Grão-Pará e Maranhão, v. 2, p. 62; Ofício de Luís Diogo Lobo da Silva para o Conde de Oeiras, Recife, 04/02/1761, AHU, Pernambuco, cx. 94, doc. 7.481. Poucos anos depois, em 1771, o governador de Pernambuco, Manuel da Cunha de Menezes, afirmou ao Secretário de Estado da Marinha e Ultramar sobre os desentendimentos dos colonos com a Companhia que "o povo é um monstro de extraordinária grandeza, este nunca sabe o que quer, nem o que lhe convém, nem olha para os seus próprios interesses, e está só pronto a repetir aquelas primeiras coisas que ouve, sem nelas fazer a devida reflexão". AHU, Pernambuco, cx. 110 , doc. 8.512 .

34 Manuel Joaquim Rebelo, Economia política feita em 1795 por M.J.R. Lisboa: Banco de Portugal, 1992, p. 112, (Coleção Obras Clássicas do Pensamento Econômico Português, n. 4).

35 Carta particular da Junta de Lisboa para a Direção em Pernambuco sobre as disposições para o 
uma das Companhias pombalinas, a CGPP adotou logo no início de suas operações regras para crédito, "de sorte que não excedesse em dar de empréstimo soma que importasse mais da terça parte da produção dos ditos engenhos" ${ }^{36}$ assim como se praticava nos empréstimos concedidos aos produtores de vinho do Douro pela Companhia Geral da Agricultura das Vinhas do Alto Douro, em Portugal. ${ }^{37}$

O crédito disponibilizado pela Companhia na forma de vendas a prazo das fazendas europeias e o dinheiro emprestado diretamente ao produtor eram mecanismos arriscados para a Companhia, pois, embora a instituição tivesse se utilizado do expediente do endividamento para subvalorizar produtos coloniais e fidelizar a produção futura dos engenhos, com preços preestabelecidos, as fazendas europeias precisavam ser pagas e o dinheiro a contado saía dos caixas da empresa. Isso significou que, mesmo que a Companhia não obtivesse prejuízos com esses tipos de empréstimos, pois ela retornava os ganhos de outra forma, o negócio era arriscado. No entanto um dos mais rentáveis mecanismos creditícios residia na escravatura e seus processos correlatos e, embora o tráfico envolvesse altos investimentos, o fato da Companhia monopolizar a venda de escravos na colônia lhe permitia assumir os riscos do investimento e possibilitava retorno de capital, sobretudo, no endividamento da produção com o adiantamento da escravatura.

As atividades mercantis da Companhia em torno do negócio do tráfico africano foram recentemente analisadas pelo historiador Maximiliano Menz, que num de seus artigos problematiza os aspectos do financiamento, negociações e lucros obtidos por parte da Companhia no resgate de escravos em Angola durante praticamente todo o período de vigência do monopólio. Utilizando-se dos Livros de Demonstrações da Companhia, dados publicados nas obras clássicas de Antônio Carreira,

comércio da Companhia, Lisboa, s.d., Manuscrito, ANTT, Junta da Liquidação da Companhia de Comércio de Pernambuco e Paraíba, Documentos e papeis diversos, cx. 625, capilha 4.

36 Carta da Junta de Lisboa para a Administração em Pernambuco, Lisboa, 1761, AHU, Pernambuco, cx. 96, doc. 7.536. Sobre as teorias institucionais acerca da imitação de práticas de sucesso e emulação, ver: Sophus A. Reinert, Translating Empire: Emulation and the Origins of Political Economy, Cambridge, MA: Harvard University Press, 2011.

37 José Miguel Pereira dos Santos, "A contabilidade e o equilíbrio de interesses: o caso da Companhia Geral da Agricultura das Vinhas do Alto Douro (1756-1826)" (Tese de Doutorado, Universidade do Porto, 2014), p. 60. 
e das listas de viagens e exportações de escravos de The Transatlantic Slave Trade Database, o autor analisa novos dados, recoloca debates e proposituras historiográficas no seu devido lugar e traz novos elementos para reafirmar uma antiga tese defendida por Joseph Miller: "eram os homens de negócio sediados em Portugal que financiavam o tráfico em Angola". 38

Nosso ponto de partida para a questão, portanto, leva em consideração que o ramo das atividades mercantis em torno do tráfico africano dependeu, em sua grande maioria, dos capitais e fazendas agenciadas no Reino e enviadas para Angola: as cargas originadas em Lisboa chegaram a 74\% de todo o capital investido nas negociações. Em primeira instância é possível afirmar que esse montante investido em mercadorias para o resgate não seja exatamente reinol, mas fruto das muitas negociações da Companhia. Ou seja, embora as fazendas europeias tenham um peso muito maior na aquisição da escravatura, parte dessas mercadorias foi comprada com o açúcar e os couros oriundos do norte do Estado do Brasil. Colocado dessa forma, o problema da origem das mercadorias parece ser menor que o do giro do capital e das muitas negociações que a Companhia foi capaz de realizar para, inclusive, adquirir mercadorias europeias para o tráfico negreiro e enviar diretamente de Lisboa para Luanda.

Ainda no segundo semestre de 1760, a Junta em Lisboa se preparava para enviar a segunda galera com efeitos europeus para Angola. A demora do envio se dava pela falta, em Lisboa, dos produtos necessários à carregação que tinham melhor apreço no negócio da escravatura. No entanto, em que pese o desejo da Junta da Companhia em somente trocar mercadorias por escravos, as negociações em Angola não puderam ser exatamente assim. Letras e mais letras foram passadas pela Companhia para serem sacadas sobre negociantes portugueses instalados em Luanda, assim como ocorreu sobre a Direção em Pernambuco e negociantes no Rio de Janeiro. Além de dinheiro de contado, patacas, ouro e fazendas da Índia, a Companhia teve que dispor de crédito para os negociantes do sertão e pumbeiros, ou seja, aqueles que estavam relacionados diretamente ao apresamento nas matas de Angola. Esse crédito vinha por 
meio do adiantamento de fazendas europeias já existentes nos armazéns da Companhia em Luanda, ou mesmo do repasse de dinheiro para ser pago em escravatura. A concorrência da Companhia com negociantes portugueses e estrangeiros que enviavam escravos para outras praças do Brasil e do Mundo tornava o negócio competitivo e, portanto, "se ter abundância de fazendas e extensão de crédito dá [dava] maior facilidade para dominar nas ações do Comércio". ${ }^{39}$

Outro ponto relevante é a questão do tráfego atlântico e o mercado de fretes gerenciado em cada escala diferente das viagens negreiras da Companhia, pois a importância do negócio dos transportes se dá pela própria natureza da navegação mercantil e o transporte marítimo é um ramo do negócio. Seu plano de ordens, que pode objetivamente levar efeitos europeus até Angola, trocar por escravos, negociar no Recife e voltar com açúcar para Lisboa, não impede que fretes entre Angola e Benguela, ou Costa da Mina e Recife sejam realizados, ampliando assim as negociações. Ao capitão António Lopes Figueira, por exemplo, no Plano de Ordens passado pela Companhia em 1777, instruiu-se que, quando saísse de Angola para Recife, aportasse em Benguela "aonde se demorará o tempo necessário para recolher aguada, mantimentos, mudar marinheiros, e o mais que vai declarado nas instruções e ordens que leva o sobrecarga Felix José da Costa" ${ }^{40}$ As instruções passadas ao capitão do navio dizem respeito à derrota (rota) do navio e às práticas de navegação (reequipagens e abastecimento), porém também fazem menção às negociações que deveriam ser feitas pelo sobrecarga do navio, ou seja, o negociante a bordo responsável pelas operações mercantis.

\section{A comercialização da Companhia na Europa}

Dentre os muitos negociantes e procuradores da Companhia que comercializaram os produtos coloniais na Europa ou que realizaram vendas

39 Carta da Junta da Companhia em Lisboa para Francisco Bruno Lemos e Antonio de Souza Portela em Luanda, Lisboa, 16/08/1765, Manuscrito, ANTT, CGPP, Livro Copiador de Angola, liv. 290.

40 Carta de Ordens passada pela Junta da Companhia em Lisboa para o Capitão Antonio Lopes Figueira, Lisboa, 04/07/1777, Manuscrito, ANTT, CGPP, Livro Copiador de Cartas para Benguela, liv. 219. 
de produtos europeus para a Companhia, destacamos Domingos Luiz da Costa, Geraldo Braancamp e Jacobus Johannes Vandeivall, em Amsterdã; Diogo Terney e Dias Santos, em Londres; D. Juan de Carrera, em San Sebastián; Roman Vienne, em Cádiz; Ettiénne Drovilhet e Patrício Joyes, em Madri; Paulo Paulsens e João Schuleuck, em Hamburgo; Luís Paylart, em Ruan; Carlos Tontio, Antonio Maria Alizery, João Batista Gervazoni e Nicolau Piaggio, em Gênova, entre outros. Todos eram orientados a realizar o negócio mais rentável. Sem preços estipulados e buscando a melhor oferta, os produtos consignados aos procuradores da CGPP deveriam alcançar o melhor preço, inclusive estocando produtos quando estes estivessem em baixa no mercado. Concorrência, livre mercado e circulação de mercadorias foram os parâmetros adotados pela Companhia para a venda de seus produtos na Europa. Uma fórmula bem diferente daquela adotada para a compra das mercadorias no Brasil.

As operações mercantis na Europa para venda do açúcar e do couro do norte do Estado do Brasil eram bastante variadas. Assim, durante os vinte anos de funcionamento, em alguns casos, companhias londrinas seguraram navios da CGPP pagos com letras sacadas em Amsterdã, lastreadas com o açúcar já negociado no ano anterior; e consideráveis quantidades de resmas de papel e tinta foram adquiridos em Gênova para seguir os mercados indianos em troca de panos a serem comercializados em Angola, tendo sido pagos com solas, atanados e couros em cabelo. As letras de crédito passadas, sobretudo em nome de negociantes das praças de Amsterdã e Londres, permitiam uma maior agilidade comercial da empresa. ${ }^{41}$ Esses créditos só eram possíveis pelos níveis de confiança e status que a empresa foi obtendo com o passar dos anos e do volume das negociações realizadas. O cumprimento satisfatório de acordos e pagamentos, o respeito aos prêmios de seguros, adiantamento das letras e taxas cambiais, assim como a boa reputação da Companhia, permitia graus elevados de confiança e, portanto, maiores numerário, letras e produtos envolvidos nas negociações, resultando em maiores lucros.

41 Ver as mais de cem cartas enviadas para procuradores e negociantes da Companhia na Europa existentes no ANTT que estiverem disponíveis para consulta: CGPP, Livro Copiador de Itália e Norte, liv. 288 e Junta da Liquidação da CGPP, Copiadores de Correspondências, cotas 622/5, $622 / 6$ e 622/7. 
Ao dimensionarmos as diferentes fases das negociações da Companhia, é possível perceber os distintos fatores e mecanismos utilizados pelos acionistas para cada etapa do negócio. Desse modo, a compra de açúcar e couros no norte do Estado do Brasil dos produtores, como foi demonstrado, era baseada no crédito gerado pelo adiantamento de fazendas europeias, escravos e empréstimos diversos; utilizavam-se da prerrogativa do monopólio e do endividamento para comprometimento de venda futura da produção, com preços estabelecidos muitas vezes com anos de antecedência e até com o congelamento dos valores cobrados; a navegação atlântica também era monopolizada e mesmo os produtores enviados por fretamento, ou seja, sem a venda direta ou consignada da Companhia e assumindo as responsabilidades, sofriam sanções e prejuízos. Esse mecanismo comercial, tratado aqui como a base para essa colonização mercantil, constitui-se de práticas para subvalorização dos preços dos produtos adquiridos direto do produtor pelos agentes da Companhia, resultando num longo processo de endividamento do primeiro, como veremos mais à frente. Por outro lado, o comércio de reexportação dos produtos adquiridos seguiam lógicas de mercado aberto e competitivo: oferta e procura, créditos e débitos e, sobretudo, margens para negociações livres, buscando sempre o melhor negócio para a CGPP, quando possível.

\section{Execuções de dívidas na colônia e novos negócios na China}

A Junta da Companhia em Lisboa, logo nos primeiros anos de funcionamento, passou a informar a Direção em Pernambuco para os problemas envolvidos com a liberação e disponibilidade de créditos da Companhia para os produtores e comerciantes do norte do Estado do Brasil. ${ }^{42}$ Quando a Companhia aproveitou-se da região colonial para sobrepor seu monopólio, ela também ofertou volumosos créditos em todos os segmentos produtivos. Com isso, do fazendeiro ao curtidor de sola, do oleiro

42 Carta particular da Junta de Lisboa para a Direção em Pernambuco sobre as disposições para o comércio da Companhia, Lisboa, s.d., Manuscrito, ANTT, Junta da Liquidação da CGPP, Documentos e papeis diversos, cx. 625 , capilha 4. 
ao plantador de algodão, do lavrador ao senhor de engenho; em escravos, fazendas, crédito e até moedas provinciais a Companhia distribuiu créditos que foram pontualmente cobrados. No manancial documental produzido pela Companhia, há longas e variadas listas de devedores, no entanto a identificação do devedor e o valor da dívida, por si, como aparecem nessas listagens, não nos dizem muita coisa.

Resolvemos, portanto, analisar as execuções de dívidas, ou seja, seu reconhecimento judicial e processo oficial de cobrança, por parte da Companhia. A discussão aqui proposta parte da análise global de 374 processos individuais de execuções de dívidas da CGPP, arroladas pelo Guarda Livro da administração dos fundos da Companhia, em Recife, entre 1765 a 1793 e constante em dois extensos códices do Arquivo Histórico Ultramarino. ${ }^{43}$

As fazendas pecuaristas denominadas "Feia" e "Arveiro", da Ribeira do Ceará, pertencentes a Manoel Ferreira Braga; as quatrocentas cabeças de gado que pastavam no sertão da Capitania do Rio Grande do Norte, de Luís Tavares Ferreira; o engenho de açúcar "Tirapuá", na Paraíba, do Coronel Manoel Correia da Silva; os engenhos "Mazagão" e "Mundo Novo", situados em Itamaracá e pertencentes a José Correa Lima; os vinte escravos e todo o engenho "Mata Redonda", com seus apetrechos de cobre e bois mansos, na freguesia de Porto Calvo, nas Alagoas, pertencentes ao poderoso Jacomé Lumachi; todos esses bens, espraiados pelo norte do Estado do Brasil, foram penhorados pela Companhia para pagamento de dívidas.

Regulado desde os Estatutos, o funcionamento da Companhia pressupunha a atuação de seu Consulado, ou seja, um organismo jurídico formado por um Juiz Conservador em Lisboa, outro no Porto e outro em

43 Antonio Ferreira de Araújo, Relação do estado das execuções que a Companhia faz a seus devedores entre 1765 a 1793, Recife, 07/09/1793, Manuscrito, AHU, Relação de Devedores à CGPP, Códices 1.155 e 1.898. Esta pesquisa também se apoiou na análise de alguns processos de execussões de dívidas da CGPP em Pernambuco, realizadas pela historiadora Teresa Marques. Ver: Teresa Cristina de Novaes Marques, “As dívidas do Senhor Jácome Lumachi: Pernambuco e a Companhia Geral pombalina”, Topoi, v. 12, n. 22 (2011), pp. 63-74; “O corpo mercantil do Recife e o descrédito de comerciantes no início do século XIX", Locus: Revista de História, v. 20, n. 2 (2014), pp. 35-49; "As dívidas do açúcar na capitania de Pernambuco (século XVIII)”, in José Vicente Serrão, Bárbara Direito, Eugénia Rodrigues e Susana Münch Miranda (orgs.), Property Rights, Land and Territory in the European Overseas Empires (Lisboa: CEHC-IUL, 2015), pp. 313-324. 
Pernambuco, “com jurisdição privativa e inibição de todos os Juízes e Tribunais". Esse "privilégio de Juiz Privativo" é o mesmo que já detinha a congênere do Grão-Pará e Maranhão, tendo os Conservadores para o "bom governo da Companhia" a prerrogativa sobre qualquer contenda relacionada à Companhia, com exceção de questões privativas entre sócios. ${ }^{44}$ Como bem afirmou José da Silva Lisboa, os Tribunais de Comércio, ou seja, os Consulados, "conhecem das causas e contratos mercantis entre os negociantes, quer sejam nacionais, quer estrangeiros, se estes não têm Privilégio de foro de algum Juiz privativo de sua Nação"; já no caso das Companhias se chamam Conservadores, "os quais conhecem em primeira instância, com recurso ao Supremo Tribunal da Justiça no lugar". De acordo com os Estatutos da Companhia, uma das atribuições do Consulado era cuidar das querelas em torno dos "fretes, avarias e mais dívidas, de qualquer qualidade que sejam" e que "se cobrem a favor da Companhia pelos seus Juízes Conservadores". ${ }^{45}$

Durante a Idade Média foi comum, dada a inexistência de tribunais corporativos, aquilo que Sheilagh Ogilvie chama de "sistema de responsabilidade da comunidade", ou seja, a possibilidade de impor represálias aos descumpridores de acordos, como não pagamento de dívidas, por exemplo. Essas represálias impostas pelos membros das corporações de ofícios ou sociedade de mercadores era o descrédito, sanções punitivas e a propagação da "má fama". ${ }^{46}$ No entanto, com os avanços do direito mercantil necessários a um mundo cada vez mais globalizado, incorporador de praças mercantis estrangeiras e da complexificação das relações comerciais, foi se formando dentro dos próprios Estados modernos a necessidade de incorporar e aparelhar a justiça mercantil, a ponto de se criarem os Consulados com seus juízes privativos em Portugal, notadamente dentro das Companhias de Comércio.

Rui Marcos chama atenção para duas características peculiares a existência de uma jus dicere em oposição a jus commune. Em primeiro

45 Instituição da Companhia Geral de Pernambuco e Paraíba; José da Silva Lisboa, Princípios de direito mercantil: vol. 7: dos tribunais e causas do comércio, Lisboa: Impressão Régia, 1811, pp. 1-2. 
lugar, a celeridade da justiça e, em segundo, a visão excludente e ideológica do funcionamento do próprio Consulado: "ao mesmo tempo que delimitava um espaço imune às investidas dos tribunais comuns, construía um círculo de irresistível forças avocatórias". ${ }^{47}$ Ou seja, uma justiça autônoma constituída dentro de uma estrutura organizativa de Antigo Regime que pressupunha, entre outros fatores, uma efetiva força do Estado e do interesse privativo de indivíduos e pequenos grupos privilegiados, tornou o Consulado da Companhia um espaço institucional de juízo arbitral e uma disciplina normativa baseada no privilégio da justiça, dos interesses mercantis e de salvaguarda dos bens da Companhia.

Entre José Antônio de Alvarenga Barros Freire, o primeiro Juiz Conservador da CGPP em Recife - homem culto, educado em Coimbra, filho de mineiros e irmão de Claudio Manuel da Costa -, e João da Silveira Pinto Nogueira, o último, pelo menos 374 senhores de engenho, lavradores, homens de negócio, fazendeiros e curtidores de sola tiveram seus bens penhorados. ${ }^{48}$

Os processos arrolados e trabalhados seguiam a mesma ritualística jurídica: ${ }^{49}$ na primeira parte do trâmite consta a data, todos situados entre 1765 e 1793, em que o juiz conservador da Companhia havia penhorado os bens do devedor, a quantia devida, os bens penhorados, a identificação do depositário e a forma de pagamento acordada pelo juiz

47 Marcos, As Companhias Pombalinas, pp. 777-781. Ver também as relevantes considerações sobre os tribunais privativos nas questões comerciais contemporâneas em John McMillan e Christopher Woodruff, "Private Order under Dysfunctional Public Order", Michigan Law Review, v. 98, n. 8 (2000), pp. 2421-2458.

48 Laura de Mello e Souza, Cláudio Manuel da Costa: o letrado dividido, São Paulo: Companhia das Letras, 2011, pp. 54-55; Francisco Augusto Pereira da Costa, Anais pernambucanos, Recife: Fundarpe, 1984, v. 7, p. 356; Luiz Geraldo Silva, A faina, a festa e o rito: uma etnografia histórica sobre as gentes do mar (séc. XVII a XIX), São Paulo: Papirus, 2001, p. 180; Ofício do juiz de fora João da Silveira Pinto Nogueira sobre a extinção do Juízo da Conservatória, Recife, 15/09/1781, AHU, Pernambuco, cx. 141, doc. 10.419, ver também, na cx. 142, o doc. 10.448, que trata sobre o mesmo assunto da extinção do juiz conservador.

49 Todos os dados a partir de agora apresentados foram extraídos do códice manuscrito com 250 páginas elaborado por Antonio Ferreira de Araújo, Guarda Livros da CGPP em Pernambuco e por nós compilado num banco de dados em formato de planilha. Em 1793, ano de finalização do manuscrito, foram arrolados 385 declarações de execuções. No entanto, por uma questão metodológica, excluimos os casos de reexecusão ou repetição de um mesmo devedor em mais de um processo, restando assim 374 processos originais. Ver: Relação do estado das execuções que a Companhia faz a seus devedores entre 1665 a 1793, Recife, 07/09/1793, Manuscrito, AHU, Relação de Devedores à CGPP, Códice 1.155. 
e aceita pelo devedor. Na maioria dos casos, o devedor era o próprio depositário dos bens, posto que "para segurança e pagamento" da dívida era necessário que eles permanecessem em sua posse. Quando o depositário era um terceiro, este era "encarregado de guardar gratuitamente alguma coisa móvel, que se fia de seu poder, boa-fé e vigilância, com encargo de entregá-la, todas as vezes que lhe for requerido pelo dono, ou por competente autoridade pública". ${ }^{50}$ Caso o devedor não pagasse a dívida ou atrasasse os pagamentos, o juiz conservador poderia deferir a "penhora por sentença", ou seja, a execução efetiva da dívida. Consta apenas dois casos em que os devedores apelaram em segunda instância para Lisboa e ambos foram indeferidos. É preciso não esquecer do preço da justiça, já que enviar um processo da colônia para o Reino requeria altos dispêndios e grande insegurança sobre o resultado do pleito.

Durante o funcionamento da CGPP em regime de monopólio na região, ou seja, entre 1760 a 1780, pelo menos 88 execuções de dívidas ocorreram, o que representa $24 \%$ do nosso universo de análise, sendo as demais após 1780 e sob a administração da Junta de Liquidação dos Fundos da Companhia. Praticamente todas essas 88 execuções tiveram que ser pagas em arrobas de açúcar branco, conduzidas diretamente para a balança da Alfândega do Recife.

Esses primeiros casos ilustram duas relevantes questões: primeiro, a CGPP não esperou pelo término de seu monopólio para cobrar as dívidas; e segundo, esse movimento de crédito para lavoura e cobrança em açúcar durante o funcionamento da Companhia evidencia o papel do endividamento como comprometedor da produção e da possibilidade da Companhia auferir maiores ganhos com preços subjugados. Após o fim do monopólio, as execuções continuaram a ser realizadas e, como foi dito anteriormente, entre 1765 a 1793 temos 374 processos de execução.

De todos os processos em que constam escravos penhorados, $83 \%$ eram devedores que possuíam, pelo menos, de um a vinte escravos cada. Esse quadro nos leva a reiterar que o preço do escravo pode, de fato, ser calculado pela quantidade de réis que lhe foi pago no ato da venda. Porém, o seu valor deve levar em consideração, além da sua capacidade 
produtiva, o fato de corresponder a um elemento creditício relevante a Companhia para a fidelização da produção e subjugação dos preços das matérias primas coloniais. ${ }^{51}$

A Companhia também aceitou como pagamento dívidas de terceiros e em regime de penhoras. Isso significou que mesmo algum negociante ou senhor de engenho que buscasse ter sua fama ilibada junta à Companhia poderia acabar em sua extensa rede de devedores. ${ }^{\mathbf{5 2}}$

A grande maioria dos 374 processos estavam já em fase de penhora dos bens, ou seja, execução deferida. Isso significa que os devedores, viúvas, herdeiros diversos ou fiadores não pagaram as dívidas e os pleitos passaram a ser efetivamente executados. Ocorre que não consta o desenrolar final do processo em todos os casos, somente a menção de que "se vai continuando a execução," porém temos alguns casos de leilões, tomadias e prisões. ${ }^{\mathbf{5 3}}$

A questão do endividamento e da execução das dívidas dos senhores de engenho é um tema que mereceria maior reflexão por parte da historiografia brasileira. Aqui gostaríamos apenas de apontar que esses casos, acima apontados, de confiscos e leilões de propriedades e prisões de devedores, podem indicar que a Companhia de Comércio teria condições mais favoráveis que os mercadores em geral para a cobrança de dívidas, inclusive superando as dificuldades dos antigos privilégios que os senhores de engenho tinham obtido da Coroa contra seus credores. Tal vantagem estaria em especial na existência do Consulado e do juiz

51 Desde o final do século XVI na América "o endividamento tornou-se uma característica estrutural nos vários setores da agricultura escravista das economias americanas, e o meio através do qual posteriormente foram financiadas as plantações, os engenhos e os navios carregados de escravos que lhes traziam mão de obra". Joseph Miller, "O Atlântico escravista: açúcar, escravos e engenhos", Afro-Ásia, n. 19-20 (1997), p. 19.

52 Agradeço aos professores Muirakytan de Macêdo e Helder de Macedo pelas informações sobre essa fazenda na região historicamente denominada Ribeira do Seridó.

53 Tivemos contato com alguns processos da Conservatória da Companhia produzidos pela Junta da CGPP em Lisboa. No entanto, até o presente momento, não encontramos processos completos da Conservatória produzidos pela Direção em Pernambuco. De todos os processos analisados, segue a lógica do juiz privativo: deferir a favor da Companhia quando isso envolvesse o patrimônio mercantil da instituição. Para termos maiores noções de como ocorriam esses processos, nos valemos da leitura e análise da Acção cível de libelo em que é autora d. Mariana Inácia de Moura e réus Leonardo dos Santos Pinto e outros, Lisboa, 25/06/1779, Manuscrito, ANTT, Feitos Findos, Conservatória da CGPP, mç. 18, n. 06, cx. 23. 
privativo e os antigos privilégios dos senhores de engenho sobre a proteção real que detinham de não execução em sua unidade produtiva e força de trabalho já não eram respeitados pela racionalidade econômica da Companhia. O importante era salvaguardar o funcionamento da unidade produtiva, apenas. Sendo assim, independentemente de um senhor de engenho ser de uma família nobre ou não, o peso dessas relações foram diminuindo em detrimento das honras creditícias acordadas entre os devedores e a CGPP.

A análise global desses processos de execução nos revela outra função poderosa que o crédito e o endividamento exerciam: a manutenção do próprio monopólio da Companhia. A grande maioria dos casos em que os engenhos penhorados são identificados geograficamente constam ser da região das Alagoas, Porto Calvo e Sirinhaém, ou seja, ficavam ao sul de Pernambuco. De fato, na porção ao norte de Pernambuco, mesmo com todas as intempéries, ainda era mais rentável enviar pelo porto do Recife do que criar rotas para desembocar no litoral do Maranhão e seguir nas frotas do norte. $\mathrm{O}$ mesmo não ocorreu com a região ao sul, muito próxima ao porto de Salvador e onde poderiam ser aventados melhores preços pelos açúcares, afinal o açúcar da Bahia detinha maior apreço no mercado. Sendo assim, defender o monopólio da CGPP era também impedir o escoamento dos produtos do sul por Salvador e, de acordo com nossas conjeturas para o caso, um dos mecanismos utilizados pela Companhia para minimizar esse contrabando foi justamente o endividamento dos engenhos daquela área.

O papel exercido pelo crédito da Companhia e, portanto, o endividamento dos colonos foi um dos pilares da colonização mercantil perpetrada pela CGPP no norte do Estado do Brasil. O Marquês de Pombal tinha tanta clarividência desse relevante mecanismo que reiterou, em 1776, poucos anos antes do fim do monopólio, que, qualquer que fosse o estado das dívidas, "tem e deve ter outras possibilidades e outro crédito que não terá qualquer particular negociante que em Lisboa compra os efeitos da Companhia para os girar por sua conta e fazer tornar em efeitos, para vender a Companhia". Em "benefício do seu interesse e principalmente do acerto e comodidade das compras", a Companhia deve primar pelos créditos, afinal seu ganho estava nessa colonização 
mercantil sobre os "moradores das Capitanias de Pernambuco e Paraíba, que sofrem um tão fechado monopólio o qual a Junta há de procurar suavizar-lhes quando pode caber nos limites de sua diligência". ${ }^{4}$

Por outro lado, ao passo que a Companhia coagia os colonos, com mandados de prisão, penhoras e leilões, a pagarem suas dívidas, ela também se preparava, às vésperas do encerramento do seu monopólio, para conquistar com capitais próprios os mercados asiáticos. Numa dispendiosa e complexa negociação entre o Atlântico e o Pacífico, a CGPP teve de reunir letras de crédito, mercadorias das mais variadas, patacas de prata, ouro, tabaco da Bahia, miçangas de Veneza e muitas outras partidas e fazendas para chegar aos mercados da China. Prestes a encerrar o monopólio da região, os Deputados da Junta em Lisboa decidiram reunir os cabedais da Companhia e recrudescer as cobranças de dívidas na região para continuar o giro do capital.

\section{A viagem do Netuno e Polifemo: o Atlântico, o Pacífico e a história conectada.}

"Todas as Nações da Europa que fazem comércio da Ásia conhecem muito bem as vantagens que de Portugal dão sobre elas". Assim escreveu o Marquês de Pombal em 1774 ao novo Governador da Índia, D. José Pedro da Câmara. De acordo com Pombal, mesmo no estado decadente em que se encontravam em sua época os negócios portugueses na Ásia, "as situações felizes dos seus portos, a língua portuguesa geral e dominante naquela parte do Mundo, o amor e o respeito que nele foi sempre transmitindo entre os naturais daquelas regiões" consagravam importantes vantagens dos portugueses sobre os mercados asiáticos. Tudo isso conquistado pelos "ilustres feitos dos Almeidas, dos Albuquerques; dos Pachecos, dos Castros, Heróis daquele feliz Século até o dia de hoje". ${ }^{55}$

54 Aviso do Marquês de Pombal à Junta da Companhia para algumas diligência nos negócios da Companhia, Lisboa, 20/04/1776, Manuscrito, ANTT, Junta da Liquidação da CGPP, Correspondência do Reino para a Direção em Pernambuco, 1759-1770, cx. 610, capilha 2.

55 Instruções dada pelo Marquês de Pombal ao Governador da Índia D. José Pedro da Câmara para o governo do mesmo Estado, 1774, Biblioteca Brasiliana Guita e José Mindlin (BBGJM) [Cópia de originais do Marquês de Pombal], B 18 b, p. 80v. 
O Marquês de Pombal sabia da importância dos negócios asiáticos para Portugal, tanto que seus planos de ampliação de negócios portugueses no Pacífico haviam sido esboçado anos antes, numa carta escrita para o Cardeal da Mota, em $1742 .{ }^{56}$ Do valor dos produtos exóticos, como chás, e artefatos luxuosos da China comprados em Macau, como biombos e porcelanas, mas também da relevância dos valiosos tecidos de Surate e Goa, na Índia, o lucro dos produtos asiáticos valia todos os esforços de negociação e navegação. ${ }^{57} \mathrm{Com}$ os produtos da China garantiam-se avultosos lucros e com os da Índia assegurava-se, além de tudo, o mercado de escravos na América. Não por acaso, a primeira companhia de comércio pombalina foi fundada em 1753 com permissão de negociar durante dez anos, em regime de monopólio, com a Índia e a China. A malfadada Companhia do Comércio da Ásia Portuguesa foi ao chão junto com Lisboa em 1755 e parte de seus capitais litigiosos compuseram o capital inicial da CGPP, como demonstramos anteriormente. ${ }^{58}$ Tão grande era a

56 "Para ser útil a Portugal o comércio do Oriente é necessário fazer-se uma poderosa Companhia, Carta de Sebastião José ao Cardeal da Mota, Londres, 19/02/1742”, in Sebastião José de Carvalho e Melo, Escritos economicos de Londres (1741-1742) (Lisboa: BNP, 1986, pp. 133-158. Ver: Fritz Hoppe, A África Oriental Portuguesa no tempo do Marquês de Pombal (1750-1777), Lisboa: Agência Geral do Ultramar, 1985, p. 299; José Acúrsio das Neves, "Observações sobre o comércio da Ásia, c.1800-1830", in António Almodovar e Armando de Castro (orgs.), Obras completas de José Acúrsio das Neves, vol. 3: variedades (Porto: Afrontamento, 1982), pp. 273-306.

57 "O sonho de chegar à China é o fio imaginário que percorre a história da luta da Europa, no início da Era Moderna, para fugir do isolamento e entrar pelo mundo mais vasto". Timothy Brook, O chapéu de Vermeer: o século XVII e o começo do mundo globalizado, Rio de Janeiro: Record, 2012, p. 55. Para debates mais amplos sobre como o comércio com a China pagava os riscos e as aventuras de um mundo cada vez mais globalizado, ver: Immanuel Wallersteins, "The West, Capitalism, and the Modern Word-System", in Timothy Brook e Gregory Blue, China and Historical Capitalism: Genealogies of Sinological Knowledge (Cambridge: Cambridge University Press, 1999), p. 10-56; Pomeranz, A grande divergência.

58 Para recentes discussões sobre os investimentos portugueses no mercado asiático, em caráter de exemplo, ver: Charles Boxer, Francisco Vieira de Figueiredo: a Portuguese Merchant-Adventurer in South East Asia, 1624-1667, Haia: Martinus Nijhoff, 1967; Jesus Bohorquez, "Globalizar el Sur: la emergencia de ciudades globales y la economía política de los imperios portugués y español: Rio de Janeiro y La Habana durante la Era de las Revoluciones” (Tese de Doutorado, European University Institute, 2016); Sanjay Subrahmanyam, O império asiático português 1500-1700: uma história política e económica, Lisboa: Difel, 1995; Luís Filipe F. R. Thomaz, De Ceuta a Timor, Lisboa: Difel, 1994. Sobre o principal investidor e interessado na Companhia de Comércio da Ásia Portuguesa, Feliciano Velho Oldemberg, ver: Philomena Sequeira Antony, Relações intracoloniais: Goa-Bahia: 1675-1825, Brasília, DF: Funag, 2013, p. 193; Leonor Freire Costa, Maria Manuela Rocha, Rita Martins de Souza, O ouro do Brasil, Lisboa: Imprensa Nacional, 2013, p. 173. 
relevância da China nos sonhos e planos portugueses que o embaixador português em Áustria, Manuel Teles da Silva, escreveu em duas ocasiões ao futuro Marques de Pombal, em 1752 e 1756, afirmando que "os Reis de Portugal podem vir sucessivamente a ter um Império, como o da China, e ainda maior que a França, Alemanha e Hungria, unidas se fossem um só corpo", caso juntasse Portugal ao Brasil. E, mesmo que Portugal ao Brasil não fosse unido, ainda assim, ao Brasil caberia tal missão, posto que o Império da China "é antiguíssimo e nada pareça mais novo que o querer fazer de tão diversos selvagens Tapuias, Negros, Mulatos, uma China do Brasil". ${ }^{59}$

Em 1776, a Direção da Companhia em Recife recebeu as instruções por parte da Junta em Lisboa para carregar "caixas de açúcar surtidas" no navio Maria Victoria, comandado naquela ocasião pelo capitão tenente do mar e guerra Domingos Furtado de Mendonça e tendo como proprietário Luiz Cantofer. Este era um negociante radicado na corte portuguesa, experimentado nos negócios na Ásia, que havia obtido licença por parte da Coroa para fazer negócios no Porto de Mocha e outros no Mar Vermelho, ou seja, em portos do oceano Índico entre a África e a Ásia. Ocorre que Cantofer recebeu permissão da Junta para portar uma letra de risco sobre a Companhia, o que denota que a negociação realizada pelo sobrecarga, ou seja, o negociante a bordo do navio responsável pelas transações comerciais em cada porto, durante a viagem se utilizaria de créditos da Companhia a serem pagos vinte dias depois do retorno do navio. ${ }^{60}$ Não sabemos precisar se essa foi a primeira negociação para Ásia de que a Companhia participava com efeitos e créditos, mas podemos afirmar que isso ocorreu a partir de 1775, a próprio, momento

59 Cartas de Manuel Teles da Silva na Áustria para Sebastião José em Portugal, Viena, 12/08/1752, 19/11/1756; Eugénio dos Santos, "O Brasil pombalino na perspectiva iluminada de um estrangeirado", Revista da Faculdade de Letras, v. 8 (1991), pp. 91-94.

60 Carta da Junta de Lisboa para a Direção em Pernambuco sobre o Navio Mariana Victória, Lisboa, 09/03/1776, ANTT, Junta da Liquidação da CGPP, Minutas de cartas, avisos, ordens, requerimentos e decisões da Junta de Lisboa, 1773-1810, cx. 625, capilha 3. Sobre os negócios de Luiz Cantofer, ver: Roquinaldo Ferreira, "Dinâmica do comércio intracolonial: jeribitas, panos asiáticos e guerra no tráfico angolano de escravos", in João Fragoso, Maria Fernanda Bicalho e Maria de Fátima Gouvêa (orgs.), O antigo regime nos trópicos: a dinâmica imperial portuguesa (séc. XVI-XVIII), Rio de Janeiro: Civilização Brasileira, 2001, pp. 359-366. 
em que a CGPP passou a se preparar para enviar uma negociação particular para a Ásia. ${ }^{61}$

Em 1775 havia chegado a Lisboa o navio Netuno, construído nos estaleiros de Recife e da Paraíba com capitais da CGPP. O Marquês de Pombal se encarregou das licenças régias, argumentando na Corte que o navio, "pela sua bondade, é capaz de ir à Índia", obtendo de D. José I a aprovação para que "o dito Navio siga a referida Viagem na forma do estilo Mercantill". ${ }^{62}$ Netuno, deus presente já entre as crenças dos navegadores fenícios, a quem na repartição dos "Domínios do Mundo" coubera o "Império do Mar", foi o nome escolhido em Recife para batizar o navio, a partir de uma lista enviada pela Junta de Lisboa. A Junta considerou que o nome da nova nau deveria se "afastar do uso comum da Navegação Portuguesa" e se aproximar dos nomes das embarcações das outras "Nações da Europa, assim se evitam as indecências com que se tratavam os nomes mais sagrados da nossa Religião". Embora levasse um nome pagão para se misturar com os nomes dos navios comuns europeus, "Santo Antônio que é o Protetor da Companhia será sempre o de toda a sua navegação". ${ }^{63}$

Dada a permissão real, em 1775, a viagem do Netuno iniciou seus longos preparativos, partindo do porto de Lisboa só em 1777. Ocorre que o plano inicial se modificou e, em vez de ir somente a Índia, estenderam a negociação até o Império da China. Para tanto, a CGPP calculou todos os riscos e ganhos possíveis, assim como a melhor estratégia de navegação, e decidiu que a viagem incluiria mais uma nau, o navio Polifemo. O comandante Dionísio Ferreira Portugal conduziu o Netuno em sua derrota estabelecida no Plano de Ordens e Viagens e, incluindo os principais portos de negociação, partiu de Lisboa para o Rio de Janeiro, Moçambique, Diu, Damão, Surrate, Goa, Madastra (Chennai) e Macau, retornando a Lisboa. Já Antônio José de Oliveira, o capitão e tenente de

61 Carreira, A Companhia Geral do Grão-Pará e Maranhão, v. 1, pp. 102, 315-316.

62 Aviso do Marquês de Pombal a Junta da Companhia sobre o Navio Netuno, Lisboa, 11/03/1775, Manuscrito, ANTT, Junta da Liquidação da CGPP, Correspondência do Reino para a Direção em Pernambuco 1759-1770, cx. 610, capilha 2.

63 Carta da Junta de Lisboa para a Direção em Pernambuco, Lisboa, 08/09/1773, Manuscrito, ANTT, Junta da Liquidação da CGPP, Minutas de cartas, avisos, ordens, requerimentos e decisões da Junta de Lisboa, 1773-1810, cx. 625, capilha 3. 
mar e guerra da Armada Real, conduziu a derrota do Polifemo: partiu de Lisboa para a Bahia, Moçambique e Goa, retornou à Costa da África em direitura para Angola e seguiu para Lisboa. ${ }^{64}$

Ambas as naus receberam efeitos europeus para serem comercializados em portos diferentes e de acordo com o seu plano de ordens particular entregue aos sobrecargas. A soma desses efeitos, distribuídos em ambas as naus, foi de 191:680\$958 réis, em produtos variados: miçangas e avelórios comprados a Jacomoto Juventa, em Veneza, e vidros da Boêmia, de Heil Millen Company, para as negociações na África, além de pólvoras e espingardas compradas, em Hamburgo, a Luiz Lassence e Joaquim Izidório Boret; efeitos de ferro, chumbo e cobre, como pregos, barras e chapas, além de papel e coral, para os portos da Ásia; açafrão, água de cheiro da Hungria, vinhos, azeites e chapéus portugueses comprados a Gonçalo Ribeiro dos Santos para comercializar na Bahia e Rio de Janeiro; e 1.016 patacas de prata castelhanas.

A nau Netuno adicionou a sua carga caixas de açúcar para o negócio em Goa e pipas de aguardente para Moçambique, quando aportou no Rio de Janeiro, além de ter recebido do procurador da CGPP naquela praça, Francisco Pinheiro Guimarães, 20:000\$000 réis em pesos castelhanos, totalizando 7.422 pesos. Toda essa prata era essencial para os negócios em Macau. A nau Polifemo recebeu na Bahia os admirados tabacos de corda adocicados, essenciais ao negócio da escravatura quando do seu retorno por Luanda ou mesmo para os negócios em Moçambique. Esse tabaco foi embarcado por conta da Fazenda Real. ${ }^{65}$

As naus também receberam uma série de cartas e instruções a serem entregues em cada porto que fundeassem. Como havia afirmado

64 Todos os registros de ordens, despachos, contratos, assim como os Planos de Navegação dos Capitães e os Planos de Ordem e Negociações dos Sobrecargas das naus Netuno e Polifemo, encontram-se no ANTT, CGPP, Negociações da Ásia, Livro de Registro das Naus Netuno e Polifemo, liv. 203. Já as diversas entradas e saídas de fazendas de todas as negociações foram registradas no Livro de Entradas das Fazendas da Índia, liv. 202. Todas as informações apresentadas sobre essas negociações e viagens constam nesses livros e, portanto, dispensaremos outras referências, salvo qualquer documentação diferente que foi devidamente citada ao longo do texto.

65 Além das referências contidas na nota 87, ver também: Fazenda expedida por conta da Companhia Geral de Pernambuco e Paraíba pela Nau Netuno para Goa, Lisboa, 24/03/1777, Manuscrito, ANTT, CGPP, Livro $1^{\circ}$ de enfardamentos para Goa, liv. 391. 
anos antes D. Luís da Cunha sobre o comércio com a Ásia em regime de Companhias, devia-se manter comissários em "todos os estabelecimentos da dominação de Sua Majestade, para tirar daquelas remotíssimas partes todas as mercadorias e produções que na Europa se consomem”. Em Goa, por exemplo, seguiram as instruções para D. Frederico Guilherme de Souza, governador e capitão general daquele estado, e José Joaquim de Cerqueira de Magalhães Lenções, chanceler da Casa da Suplicação, para dispor do apoio necessário às negociações, aguadas e mantimentos. Em Madrasta, o negociante português Antônio de Souza foi delegado como procurador dos negócios da Companhia, assim como, em Surrate, Joaquim Ribeiro Neves e, em Bombaim, Miguel de Lima e Souza e seu irmão Luis Barreto e Souza receberam cartas. Os negócios na Ásia também dependiam desses contatos e dos possíveis adiantamentos que eles poderiam realizar nas praças, portanto os negociantes da família Synay, Anta Synay, Kama Crismá Synay e Narana Synay, foram devidamente avisados dessa negociação. ${ }^{66}$

A nau Netuno, além da tripulação convencional necessária a uma viagem desse porte, carregava um experimentado negociante do trato africano e asiático, o sobrecarga Felix José da Costa, e seu auxiliar Manuel Afonso Morgado. ${ }^{67}$ Se o sucesso da navegação dependia da experiência e conhecimento do capitão, o sucesso desse empreendimento mercantil dependia da experiência, agudeza e agilidade dos sobrecargas ao realizarem cada negociação nos portos. No Rio de Janeiro, o procurador da CGPP já havia sido informado de que deveria providenciar a melhor aguardente de Paraty para o negócio da Índia, mantimentos e reparos para a nau, além de toda a prata necessária, importando tudo mais 28 contos de réis pagos em dez letras diferentes sacada sobre a CGPP, o que diminuiu o trabalho do sobrecarga ${ }^{68} \mathrm{O}$ mesmo não ocorreu em Moçambique, onde

66 Luís da Cunha, Instruções política [1736]: introdução, estudo e edição crítica de Abílio Diniz Silva. Lisboa: CNCDP, 2001, p. 322.

67 Ver as referências a esse negociante em cartas mercantis que citam negociações na Índia: "Carta de Manuel José de Carvalho em Salvador para Francisco José Vaz em Lisboa, Bahia, 01/10/1774", in Pedreira, Os homens de negócio da praça de Lisboa, p. 521; "Instruções dadas a Felix José da Costa, Lisboa, 04/07/1777”, in Carreira, As companhias pombalinas de navegação, pp. 66-68; Joseph C. Miller, Way of death: Merchant capitalism and the Angolan slave trade, 1730-1830, Madison: The University of Wisconsin Press, 1978, p. 395.

68 Cartas da Junta da Companhia em Lisboa para o procurador no Rio de Janeiro Francisco Pi- 
Felix José da Costa necessitou realizar os melhores negócios em busca de prata, ouro e marfim. Ao sair de Moçambique em direção aos portos da Índia, o sobrecarga não podia perder a oportunidade de comprar algodão em Diu, Damão e Surrate para vender no outro extremo da Índia, já para dentro do Rio Ganges e em Bengala. Nenhuma oportunidade poderia ser perdida, pois, sem essa experiência e agilidade, o negócio poderia trazer prejuízos. Ao chegar em Goa, provavelmente por volta de setembro de 1779, o Netuno encontrou o Polifemo e recebeu deste todos os caixões de prata e ouro contidas na nau, além de 42.023 pesos castelhanos provenientes dos negócios que o Polifemo realizara na Bahia e em Moçambique com o tabaco baiano. Em contrapartida, despachou os carregamentos de corjas de tecidos como chitas e linhos de Zuartes, Coromandel, Damão, Diu e Surrate, por onde passara e negociara.

Importava à nau Netuno, nessa altura da viagem, desfazer-se de quaisquer produtos que ocupassem espaço e substituí-los por mercadorias valiosas para o negócio na China. Aos sobrecargas e ao Capitão cabia também se informar sobre o estado de guerra daqueles povos, assim como o estado da navegação mercantil que ligava as Ilhas Filipinas ao comércio com a China e os ânimos comerciais em Macau, além dos negócios dos holandeses e ingleses nos portos do sul. As instruções de Lisboa diziam "logo que tiver seguras notícias, devem seguir a cidade de Macau". Para tanto, era necessário "toda a vigilância e desconfiança nas compras e encomendas que celebrarem com os Mercadores da China, a fim de acautelarem as sutilezas e enganos, que por costume e natureza praticam em todas as suas negociações". As compras todas deveriam ser realizadas à vista e, logo que o negócio fosse fechado, que se fizesse receber o produto e conduzi-lo imediatamente para a nau ou armazéns alugadas, "que estejam debaixo de suas chaves, para que não suceda que os ditos Chins os troquem, misturem ou façam outras de suas acostumadas destrezas".

Entre Macau e Cantão, tudo se pagava em prata. Importou aos mercadores chineses Singchong, Senion, Jeching, Congua, Anisa Tanchoqua e muitos outros, que receberam barras de ouro, prata limpa e 
meias dobras em troca de louças as mais variadas, porcelanas as mais ricas e chãs os mais finos. Quase dois anos depois, no final de 1780, voltava a Lisboa a nau Netuno carregada das riquezas chinesas e dos panos asiáticos. Praticamente tudo foi leiloado a preços compensatórios para CGPP e, de acordo com Mauricio José Cremer Vanzeller, acionista originário da Companhia, Deputado da Junta Liquidatória da mesma, além de renomado comerciante da praça de Lisboa, "produziu este comércio aos interessados a real e líquida utilidade de 122:923\$125 réis. Utilizou a Real Fazenda pelos direitos da Casa da Índia 68:665\$934 réis e perceberam os diversos indivíduos empregados nela 82:950\$871 réis". ${ }^{69}$

\section{Considerações finais}

No final de 1780, já findo o monopólio da Companhia na região, a Junta de Lisboa apresentou ao Secretário do Estado da Marinha, Martinho de Melo e Castro, com envio posterior de cópia ao governador de Pernambuco, José César de Meneses, um balanço sobre os investimentos e cabedais da Companhia, dando informações sobre o sucesso do negócio da China. A Junta declarou que parte dessa negociação também foi realizada pela segurança que a Junta tinha na liquidação de diversas carregações de fazendas "que se remeteram para as Capitanias de Pernambuco e Paraíba, e na venda de outras que se achavam em ser naquelas alfândegas, como também nas somas que os moradores das ditas duas capitanias estavam devendo à Companhia". Essas fazendas, "vendidas a crédito, e parte pelos adiantamentos e suprimentos de dinheiro, escravos, e outros diversos gêneros, com que a mesma Companhia assistiu aos proprietários de engenho, lavradores e fabricantes", naquele momento orçavam em, pelo menos, 1.599:034\$640 réis e, portanto, esse "estado atual da referida Companhia, a sua maior vantagem consistia na efetiva cobrança das suas dívidas". A Junta também reiterou que, ao passo que as cobranças deveriam ser executadas, o giro do capital de avultadas somas existentes em fazendas e numerários da CGPP não poderia ficar parado, posto

69 Carta de Maurício José Cremer Vanzeller ao Governador de Moçambique, Lisboa, 04/12/1784, Manuscrito, AHU, Moçambique, cx. 48, doc. 37. Sobre Vanzeller, ver: José Accursio das Neves, Noções históricas, económicas e administrativas sobre a produção e manufaturas das sedas em Portugal, Lisboa: Imprensa Régia, 1827, pp. 304, 339. 
que não "seria possível conseguir-se a cobrança das Dívidas da mesma Companhia, nem as vendas de muitas Fazendas que ainda se acham em ser, senão pela continuação do mesmo Comércio". ${ }^{70}$

Em 1782, a Companhia enviou sua segunda viagem aos mares da Índia e China. Dessa vez, a longa viagem mercantil foi realizada pelas naus Conceição e Príncipe do Brasil, nos mesmos termos que outrora foram Netuno e Polifemo. A Companhia não podia simplesmente fechar suas portas, ${ }^{71}$ pois o "civil progresso deste novo giro" fez a CGPP adquirir grande crédito em todas as praças do Oriente, "mandando-se novamente girar para os Portos da Ásia aquela soma que se está devendo aos Depósito Público e os avanços que esta tem produzido nas expostas negociações, a fim de se multiplicarem os interesses da Companhia", como afirmou um acionista originário e agora integrante da Junta de Liquidação, em $1784 .^{72}$

As negociações da Companhia para adquirir os produtos asiáticos exigiram transações com diversos mercadores que atuavam nas praças e portos de Lisboa, Porto, Recife, Salvador, Rio de Janeiro, Luanda, Goa e Macau, prioritariamente. O sucesso dessa empreitada só se efetivou com a segurança oferecida pela Coroa portuguesa e seus interlocutores e funcionários presentes nessas praças que auxiliaram na salvaguarda e defesa das naus e seus tripulantes. Sendo assim, é possível afirmar que, no século XVIII, os grandes e bem sucedidos negócios do Império português estavam relacionados, em maior ou menor medida, à Coroa portuguesa; requeriam pluralidade de negócios em praças mercantis na Europa, América, África e Ásia; dependiam de alta dispersão e rotação de capital; necessitavam de grandes investimentos de créditos e capitais, que poderiam ser em numerários e letras, bem como em variados produtos estrangeiros; e dependiam da liquidação e negociações nas diver-

70 Consulta da Junta da Companhia em Lisboa sobre os investimentos e cabedais da Companhia, enviadas a Martinho de Melo e Castro, Lisboa, 11/12/1780, ANTT, Companhia de Comércio de Pernambuco e Paraíba, lv. 395.

71 Angélica de Vasconcelos Silva, “As portas não podem ser cerradas (1780-1813): o processo de liquidação da Companhia Geral de Pernambuco e Paraíba” (Tese de Doutorado, Universidade de São Paulo, 2016), pp. 289-292.

72 Diário da viagem da Nau Conceição na sua viagem à China e Índia, 1782, Manuscrito, ANTT, CGPP, Diário n. ${ }^{\circ}$ A, liv. 204; Carta de Maurício José Cremer Vanzeller ao Governador de Moçambique, Lisboa, 04/12/1784, Manuscrito, AHU, Moçambique, cx. 48, doc. 37. 
sas praças, inclusive no Brasil e, não menos importante, da participação efetiva de negociantes portugueses em escalas e instituições distintas.

Recebido em 07/02/2018 e aprovado em 09/05/2019 


\title{
Resumo
}

A Companhia Geral de Pernambuco e Paraíba, sociedade mercantil formada com capital acionista e com intervenção diretiva e financeira da Coroa portuguesa, foi fundada em 1759 por negociantes portugueses com apoio do Marquês de Pombal e operou entre 1760 e 1780, em regime de monopólio comercial no Norte do Estado do Brasil, ou seja, nos territórios de Alagoas, Pernambuco, Paraíba, Rio Grande e Ceará. Com negócios em escala global de produtos americanos como o açúcar, pau-brasil e couros, essa companhia operou importantes mudanças no cenário mercantil colonial, notadamente na região em que deteve o monopólio comercial durante seus vinte anos de funcionamento, como preceituava seus estatutos. Depois de 1780, mesmo com a perda do monopólio, a Companhia não deixou de existir, tendo atuado na cobrança de dívidas dos negociantes na colônia, assim como na realização de negócios, com capitais próprios, como foi o caso de sua primeira viagem mercantil para a China. Este artigo visa analisar, a partir de uma perspectiva institucionalista, aspectos formais da formação e do funcionamento dessa companhia até o momento de realização de sua empreitada mercantil privativa na China, contribuindo para o debate sobre o papel do endividamento, do adiantamento da mão de obra escrava enquanto crédito e da rentabilidade dos negócios coloniais no aperfeiçoamento e giro do capital dos negócios mercantis europeus.

Palavras-chaves: Companhia Geral de Pernambuco e Paraíba - capital acionista - monopólio comercial - dívidas - negócios na China.

\begin{abstract}
The General Company of Pernambuco and Paraiba, a mercantile society formed with shareholder capital and with financial and directive intervention of the Portuguese Crown, was founded in 1759 by Portuguese merchants with the support of the Marquis of Pombal and operated between 1760 and 1780, under a commercial monopoly over the north of the State of Brazil, that is, in the territories of Alagoas, Pernambuco, Paraiba, Rio Grande and Ceará. With a global scale of trades involving American products such as sugar, brazilwood and hides, this company operated important changes in the colonial mercantile scenario, notably in the region where it held commercial monopoly during its twenty years of operation, as stated in its bylaws. After 1780, even with the loss of the monopoly, the Company did not cease to exist and collected the debts of the merchants in the colony and continued to do business with its own capital, as observed in the case of its first business trip to China. This article aims to analyze, from an institutionalist perspective, formal aspects of the formation and functioning of this Company until the very moment of carrying out its private mercantile venture in China, contributing to the debate on the role of indebtedness; the advance of slave labor as credit; and the profitability of colonial businesses in improving European mercantile business and in its capital turnover.
\end{abstract}

Keywords: General Company of Pernambuco and Paraiba - shareholder capital commercial monopoly - debt - business in China. 
